\title{
Learning Activities for Social Skills in Elementary School
}

\author{
Moh Salimi", Achmad Dardiri, Sujarwo \\ Primary Education Doctoral Program, Graduate School, Universitas Negeri Yogyakarta, Indonesia
}

Received July 1, 2020; Revised August 21, 2020; Accepted September 11, 2020

\section{Cite This Paper in the following Citation Styles}

(a): [1] Moh Salimi, Achmad Dardiri, Sujarwo , "Learning Activities for Social Skills in Elementary School," Universal Journal of Educational Research, Vol. 8, No. 11, pp. 5222-5236, 2020. DOI: 10.13189/ujer.2020.081123.

(b): Moh Salimi, Achmad Dardiri, Sujarwo (2020). Learning Activities for Social Skills in Elementary School. Universal Journal of Educational Research, 8(11), 5222-5236. DOI: 10.13189/ujer.2020.081123.

Copyright $\mathrm{C} 2020$ by authors, all rights reserved. Authors agree that this article remains permanently open access under the terms of the Creative Commons Attribution License 4.0 International License

\begin{abstract}
The 21st-century skill that guides a person to achieve success in his social life is social skill. This study aims to describe learning that influences the social skills of elementary school students. Social skill indicators include cooperation, assertion, responsibility, empathy, and self-control. Qualitative research method with a case study approach was employed. The subjects involved the students, teachers, and school principals at Bengawan Solo Nature School. The sampling technique was purposive. The data collection techniques were in-depth interviews, non-participant observation, and document studies. Then, they were analyzed into stages: data reduction, data display, and conclusion drawing or verification. The results show that (1) lesson planning must involve students, be guided by the national and school curriculum, and the teacher must also have broad insights to develop learning materials that raise the themes of social environment; (2) learning implementation must have diverse methods, models, media, and the sources of student learning must involve parents and provide diverse activities such as outbound, market day, backpacking, social service, social projects, and counseling; and (3) for learning evaluation, various methods of evaluation and various assessment instruments are used to assess cognitive aspects, affective aspects, and skill aspects comprehensively. It concludes that learning at Bengawan Solo Nature School influences the development of students' social skills.
\end{abstract}

Keywords Social Skills, Activity, Learning, Elementary School

\section{Introduction}

In this $21^{\text {st }}$ century, education is essential to ensure students have the skills to learn, innovate, use technology and information media, work and survive. To improve $21^{\text {st }}$-century education, the Ministry of Education and Culture of the Republic of Indonesia innovates by developing the 2013 Curriculum which emphasizes strengthening students' life skills [1]. Life skills are the skills of a person to be willing and brave in facing life's problems appropriately without any pressure and to seek and find solutions to solve the problems in life proactively and creatively [2]. The types of life skills include self-knowledge, personal, academic, social, integrity, and thinking skills [3],[4].

The $21^{\text {st }}$-century skill that guides a person to achieve success in his social life is social skill. Social skills are a component of social behavior that is needed by individuals to interact socially to get positive feedback from others and avoid the negative effects [5],[6]. This is as stated by [7] that social skills are behaviors that are oriented to social norms and depend on the social context. In other words, social skills are behaviors that are analyzed from the perspective of social reasoning [8]. It means that a person's social behavior that includes observable and unobservable social and emotional skills is assessed based on positive, neutral, or negative responses from the community [9].

Social skills are defined from the perspective of intrapersonal skills and interpersonal skills [10]. From the intrapersonal perspective, social skills are defined as emotional intelligence which includes the ability to 
identify, understand, and manage self-emotions related to the situations of social life [11],[12]. From the interpersonal perspective, skills are defined as specific behaviors that can be learned and depend on certain situations so that individuals can interact and communicate with others effectively [11][13].

The forms of social skills are divided into several skills such as (1) foundation skills in the form of gesture \& mimic; (2) interaction skills in the form of the ability to do conversations, resolve conflicts, and maintain interaction; (3) emotional skills in the form of the ability to empathize, understand the other person's mimic, and choose the one who can be trusted; and (4) cognitive skills in the form of understanding social norms, identifying appropriate behavior based on the situation, as well as social perception [14]. On the other hand, social skills are considered as a set of abilities such as communication, assertions, expression, emotion management, supportiveness, adjustability, and interaction management [15],[16]. [17] described the components of social skills including social comprehension, social behavior, and emotion management skills. On the other hand, [18] suggested that social skills consist of a set of behaviors such as expressive behavior, non-verbal behavior, social perception or receptive behavior, and interactive behavior. Overall, [9] explained that social skills include several abilities such as self-cognition, self-control, social awareness, effective communication, and decision-making. This study uses social skill indicators proposed by [19] and [20] which include cooperation, assertion, responsibility, empathy, and self-control.

Children need to have social skills so that they can be accepted in their environment, solve the problems with others better, sharpen other life skills, help to reduce difficulties at school, and be more enthusiastic in school, by which their achievements will be more optimal and they can enjoy life and be happier [21][22]. This is in line with the opinions of several experts [23]-[25] stating that social skills are very important for children because with social skills, children can work together with others as they grow, develop, and have the confidence so that they can adjust themselves in the right environment. Social skills are important in increasing our interactions with others such as increasing communication certainty, understanding and being understood more easily, and preventing misunderstandings [26] because it is important for us to interact with clarity [27]. Social skills enable individuals to empathize with other people's problems, think of ways to solve these problems, be willing to listen to others, and work well with their groups [5],[28]. This is an important component in one's career in the future [29].

However, many students have low social skills. This is reinforced by the findings of [30]-[34] showing the low social skills of students. Some of the students' behaviors with low social skills include doing vandalism at school, fighting, taunting each other, borrowing without permission, speaking harshly, skipping school, and cheating. Low social skills also lead to anti-social behaviors such as brawl [35],[36]. Students who have poor social skills will be very likely to be rejected by their peers [37] because they cannot cooperate, adapt to their environment, empathize, obey the rules, and respect others [31],[32][38].

The phenomena show how important life skills are for children, especially students who stay at school for approximately eight hours every day. Their presence at school is the responsibility of the teachers as educators. Social skills can be trained and taught to students through the teaching and learning process [34],[37].

Learning received from childhood through educational institutions is very effective in developing standards of behaviors that are delivered based on the norms adopted by the social environment [39]. Learning activities in schools, especially in the classroom, are not only the process of transferring knowledge, but, more importantly, they are also the process of training the students to have good attitudes, behaviors, and social relationships with other school members such as living in harmony, communicating well, participating in group learning discussions, and pouring their thoughts and ideas in the group to create conducive learning activities, etc. [6][17],[23]. This is in line with the opinion of [40] stating that learning is not only to form students who are ready to work but also to equip students with sustainable life skills, good personality, social skills, academic skills, and vocational skills.

Learning as a process consists of three stages of planning, implementing, and evaluating [1],[41] Planning is the process of preparing learning to be carried out based on the set goals considering the needs and duration of implementation [42]. Implementing is the application stage of the planning design created by the teacher; in other words, it is the operational learning activity [1]. In this stage, there is a teaching and learning interaction between the teacher and the students through the application of various learning methods and techniques, as well as a set of media or environment as a learning resource. At the learning evaluation stage, the teacher will assess the learning process that has been done. Evaluation is used as a measurement of achievement of learning objectives set at the planning stage [43].

According to [44]-[46], in the learning of social skills, teachers are expected to be able to apply a student-centered approach so that students actively engage in the learning process, use varied learning methods, prioritize student learning experiences directly, and demand student collaboration. It is expected that teachers choose social and environmental issues as the source of learning to enable the students to think critically and solve social problems that arise. Finally, evaluating the results of social-skill learning can be seen by carrying out direct observations of the aspects of students' social skills. 
There are many types of schools in Indonesia, one of them is the nature school. It is a concept of education promoting the natural environment as source and learning media to solve problems based on the environment around students [47]. Nature school emphasizes the concept of back to nature and learning through play. The nature school strengthens interactive learning methods so that students have wider imagination and creativity, learning activities occur in outdoor space, and students experience more than memorize various theories and encourage students to discover, find solutions, and examine things deeply. Therefore, students become more critical and creative thinkers [48]. Characteristics of nature schools in Indonesia include interacting and preserving the surrounding environment, utilizing the surrounding environment as learning resource and media, and creating the surrounding environment as place of learning [49][50].

Bengawan Solo Nature School is a part of the Taruna Bengawan Solo Foundation's educational programs with a curriculum oriented to leadership attitude, scientific thinking, life skills, talent mapping, entrepreneurship, and love and care for the environment. There are 4 curricula applied, namely moral, cognitive, leadership, and business curricula. Bengawan Solo Nature School has a mission to be a school that is always creative, innovative in developing a space for the learning process of goodness for the inside and outside the community to create a harmonious environment. The learning objectives at Bengawan Solo Nature School are student-centered, to create human beings who have a social interest, leadership, and care for the environment. The school also gives freedom for the students to build their own learning experiences in nature with a variety of models, methods, and learning resources.

Based on the explanation above, this study aims to describe learning that has an impact on the social skills of elementary school students. This is due to the lack of literature on learning social skills. The results of this study can be used as an illustration and guidelines for social-skill learning, especially at the level of elementary school.

\section{Materials and Methods}

Qualitative research method was applied in this study. Qualitative research is often referred to as a naturalistic research method because it is carried out in natural conditions. Qualitative research is a research procedure that produces descriptive data from social phenomena in the form of written words [51]. The research approach is case study. Case study is defined as in-depth and thorough research on an object in the form of events, situations, processes, programs, and activities [52]. This study examines in-depth activities in the form of social-skill learning of Bengawan Solo Nature School students.

The subjects included the students, teachers, and school principals. Purposive sampling technique was employed by setting specific criteria that fit the research objectives so that it was expected to answer the research problem [53].

The data collection techniques were in-depth interviews, non-participant observation, and document studies. Direct interviews were conducted by asking questions related to the research topic. Observation is a technique used to collect research data by observing and sensing to get more real and detailed pictures of an event. The research data are based on what the researcher sees, hears, and feels during observation. Non-participatory observation was carried out, in which the observer did not participate in the observed activity but acted as someone who was observing without having to go directly into the field. Then, the document study was carried out by in-depth studies and analyses on the documents related to the research topic. The documents can be in the form of a record of events that the teacher wrote for students, field notes, minutes, photo archives, journals, student worksheets, and others.

The data were then analyzed through the stages of data reduction, data display, and conclusion drawing or verification [54]. The data reduction stage is the stage where data are selected, summarized, grouped, directed, focused, or even discarded based on specified criteria. Then, data display is an activity to compile qualitative data in the form of narrative texts (field notes), matrices, graphs, networks, and charts so that the data are well organized and arranged in a relationship pattern for better understanding. Finally, conclusion drawing or verification consists of tentative and final conclusions. The initial conclusion is also called interim conclusion and may change if there is no strong evidence to support the next stage of data collection. However, if the interim conclusion is supported by valid and consistent evidence along the process of data collection, it can be made as a credible final conclusion.

\section{Results}

\subsection{Learning at Bengawan Solo Nature School}

\subsubsection{Lesson Planning}

The lesson planning process at Bengawan Solo Nature School is different from other formal schools. It involves student participation. Although the learning material is chosen by the students, the subject matter is tailored to the national curriculum. The school only takes the core part of the national curriculum and develops it according to the four pillars of the curriculum in nature schools. The school will choose a major theme at the beginning of each semester; then, it is developed by each class according to the level and ability of the students.

To determine students' interest in learning, the teacher distributes a questionnaire about the choice of material to 
be studied. The results of the questionnaire are analyzed and discussed by the teacher and students so that all members are involved in the selection of learning materials. All inputs from the students are noted by the teacher and made into a learning concept map called Spider Web. From this Spider Web, the concept is further elaborated by the teacher into detail activities. Detail activities contain planned activities to be carried out for one week which are almost the same as the lesson plans in other schools. Those meet the interview results:

Question: "How is the learning preparation process carried out at SD Alam Bengawan Solo?"

"Learning preparation is described in details activities which are the scope of the spider web curriculum. Details activities contain the time of implementation, details of competencies, subject matter to be taught, sub-material to be taught, learning activities, learning methods, and learning media. Every beginning of the week, the teacher always refers to the ongoing conditions and links to the lesson plan in the detail activities. If the lesson plan is still relevant to the events of the week, it will proceed; if not, the teacher will change the lesson plan to fit the existing conditions."

The daily preparation of the teacher includes looking for teaching materials from various sources. They will combine teaching materials obtained from books and the Internet. Besides, the students usually increase their literacy by reading the books in the library and reading corners. They are accustomed to being trained to think critically, thus the teacher have to master the material being discussed. Besides looking for teaching materials, there are several other preparations made by the teacher. Some classes have more than one teacher because there are quite a lot of students in grades 2 and 4 . Before starting learning, the two teachers will coordinate with each other regarding the division of tasks in the implementation of learning.

This is supported by the results of the interview with the fifth-grade teacher:

Question: "How is the learning planning strategy at SD Alam Bengawan Solo?"

"We as teachers coordinate with each other for the division of tasks both in learning activities and activities outside the classroom. So, we plan the schedule in one week, 3 days as the main teacher, and 3 days as a co-teacher. We also coordinate for learning preparation activities such as preparing learning materials, lesson plans, and learning scenarios together, as well as making a list of media needed for one week of learning in detail activities."

Daily lesson planning is also done during the closing session with the students. When closing the class, the teacher will show the next material to be studied. The teacher also updates the next material and learning needs via social media. The planning shows the seriousness of the school and the teacher in planning learning in accordance with student interests. This study analyzes one of the learning planning documents as follows:

Table 1. Lesson Plans

\begin{tabular}{|c|l|l|l|}
\hline Curriculum Aspects & \multicolumn{1}{|c|}{ Materials } & \multicolumn{1}{c|}{ Activities } & Method \\
\hline Moral (Spiritual) & Moral Spiritual & $\begin{array}{l}\text { Dhuha Prayer in congregation } \\
\text { Dhuhr prayer in congregation } \\
\text { Memorize the Qur'an } \\
\text { Study the contents of the Quran } \\
\text { Understand and memorize daily prayer } \\
\text { Apply patience and gratitude during the trip }\end{array}$ & Practice \\
Class
\end{tabular}




\subsubsection{Learning Implementation}

Student-centered learning is carried out, where every student is treated according to their abilities and interests. The teachers in this school act as the second parents who always guide their children in learning. They do not dictate the students to study. They also involve parents to improve the performance of their students.

There are many interesting things in the implementation of learning in this school, for example, the use of the discussion method in learning. The discussion method is applied in all classes, both lower and higher classes. Although the lower class is more likely to accept rather than to give an opinion, the teachers agree the learning process is more important than the result. This discussion arises a sense of wanting to learn and shapes students' learning motivation. This is supported by the result of the interview:

Question: "How is the learning strategy applied in the teaching and learning process at SD Alam Bengawan Solo?"

The second-grade teacher stated,

"The teacher does not fully play a role as a decision-maker in the lower-class discussion. The teacher only provokes the students with various questions to enable them to think critically so that they can make their own decisions. All the results of the discussion will be carried out by all the students; the teacher will not refute. If the decision is felt to be incorrect, the teacher will give more questions about the impact of the decision."

Meanwhile, the fifth-grade teacher stated,

"Unlike the lower class, discussion activities in the higher class are more like small group discussions. At the beginning of learning, small groups of diverse members are formed. The students who are often passive in class will be grouped with active students. The role of the teacher is only to provide the subject matter to be discussed. Then, the teacher leads the discussion so that it runs well and is on the right track."

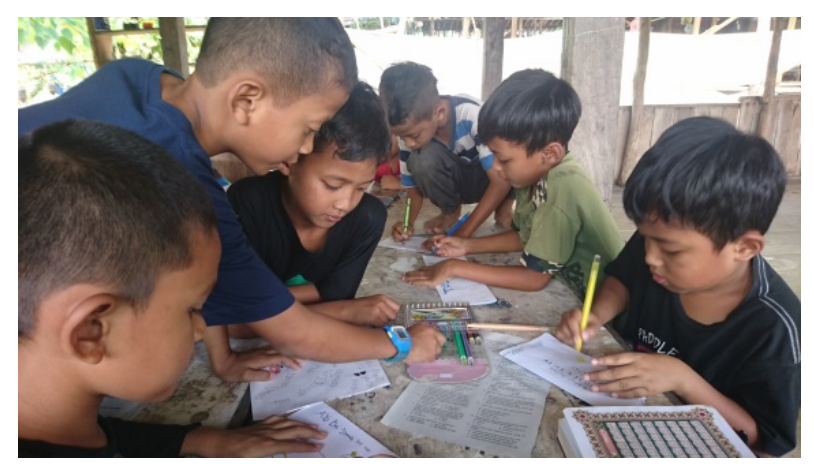

Figure 1. Students' group discussion on the learning process

In addition to the use of the discussion method, an outing class is often carried out. Outing class is one of the activities in the cognitive and science curriculum. It is usually held in the middle of the theme or midterm. The purpose of the outing class is adjusted to the learning objectives to be achieved. This fact is supported by the interview to the principal:

Question: "How is the outing class process implemented in SD Alam Bengawan Solo?"

"Outing class activities are held routinely and tailored to the needs of learning materials so that the activities and objectives of each class vary. For example, the fifth-grade students study about eels by going to the rice fields to learn about the life of an eel while the sixth-grade students who study about catfish go to the catfish farm. There, they learn about catfish, from how to breed to how to care for catfish. Students should do many things in an outing class, such as making a proposal before the class and making an observation report to be presented in front of the class."

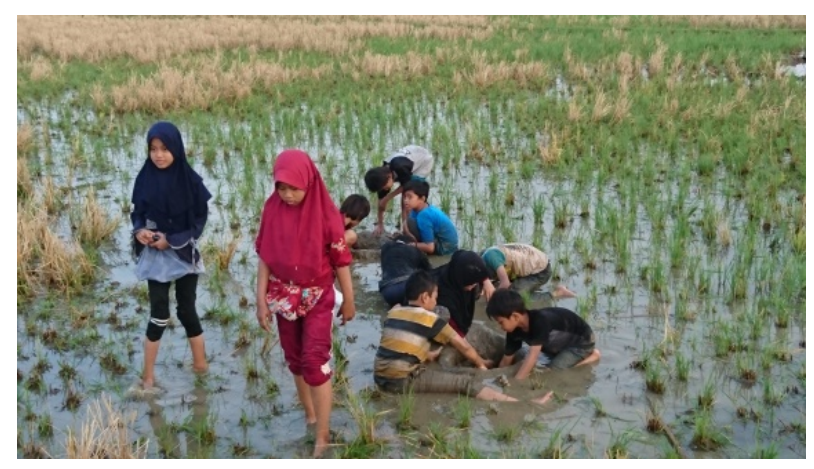

Figure 2. Outing Class

Some used learning models are innovative learning models that demand critical-thinking skills and student involvement. These learning models include outdoor learning, natural environment approach, problem-based learning model, and project-based learning model. Then, the used learning media are also diverse and tailored to the level of cognitive development of students, which is in the concrete operational stage. This is indicated by the results of the interviews with the fifth- and sixth-grade teachers:

Question: "Do the teachers use learning media in the teaching and learning process at SD Alam Bengawan Solo?

Would you provide the examples?"

"There are so many media that can be used as learning media. Because the concept is a nature school, the school never runs out of ideas to find learning media. The teachers are accustomed to using objects as the media so that the delivered material can be well received by the students. The students are always confronted with concrete objects to support the teaching and learning process. This makes the students understand the material more easily." 
The school never limits the students in getting learning materials. They are given the freedom to look for learning materials from anywhere, books, the Internet, or the surrounding environment. It is as mentioned by the fourth-grade teacher in the interview results:

Question: "What facilities does SD Alam Bengawan Solo provide for students?"

"The school provides a library with a large and varied collection of books. Besides, there are also bookshelves in every corner of the school. This makes the level of literacy culture at the school high. In addition to the provision of books, the school also provides computers connected to the Internet that are often used by the students as learning resources to look for things not found in the reading books at the library. The surrounding environment is also a part of learning resources."

\subsubsection{Learning Evaluation}

Learning evaluation is conducted every day at the end of learning, usually one hour before the learning ends, in the form of questions and answers between the teacher and students. The teacher asks about what the students have learned and what problems they face. If there is any problem, the teacher will solve it as soon as possible.

Learning evaluation does not always take the form of exam questions. There are many ways and tools of assessment carried out such as worksheets, portfolios, interviews, project presentations, and works. The worksheets are practical work reports that contain the results of activities. Through worksheets, students learn how to write a report while taking responsibility for what has been done. Those meet the statement of the fourth-grade teacher in the interview results:

Question: "What are the forms of development evaluation applied at SD Alam Bengawan Solo?"

"One example of using a worksheet as a learning evaluation tool is when the fourth-grade students hold market day on Wednesday. After they finish the selling and buying activities, they fill out the worksheets containing reports on the results of such activities starting from the planning stage, capital collection, to profit calculation. Each student analyzes the advantages and disadvantages through the worksheet."

The results of the analysis of the worksheet will then be presented to the class. The students are taught to do public speaking to increase their self-confidence. After the presentation, they do questions and answers. The teacher and the students will ask questions to each other about the progress of the project implemented. This interaction can increase the sense of responsibility and social relations between the students and the teacher.

The teacher also observes student development. The observations will be made into a daily journal which will then be reported to the parents. There are four pillars of observed curriculum, namely moral, leadership, logic, and entrepreneurship. If students have any problems, the teacher will trace the issue to the personal life of the students. It is often for the teacher to stay overnight at a student's house to find out how his home life is like until the teacher discovers the core problem to be solved wisely.

All student evaluations will be reported to their parents at the end of the semester in the form of a final report. There are two types of final reports, namely the final report according to the format of the Department of Education and Culture and the final report typical of Bengawan Solo Nature School. This is supported by the interviews to the principal:

Question: "How is the process of student learning outcomes report at SD Alam Bengawan Solo?"

"The report from the school takes the form of descriptive narratives about the development of students for one semester in the fields of morals, leadership, logic, and entrepreneurship in accordance with the applicable provisions at every level. The progress of each student will be explained in the final report and submitted to their parents."

\subsection{Social Skill Learning Activities at Bengawan Solo Nature School}

\subsubsection{Cooperation}

Cooperation is a form of social interaction in which there are certain activities aimed at achieving a common goal. Cooperation usually involves the division of tasks, where each person does the task assigned to him. The principles of cooperation include goal orientation, putting common interests before individual interests, and giving mutual benefits. The activities that influence the formation of indicators of the cooperation aspect are summarized in the following Table 1 .

Table 1. Activities and Indicators of Cooperation Aspect Formed

\begin{tabular}{|l|l|}
\hline Activities & Indicators of Cooperation Aspect Formed \\
\hline $\begin{array}{l}\text { Outbound and } \\
\text { out tracking } \\
\text { fun adventure }\end{array}$ & $\begin{array}{l}\text { Able to work with others } \\
\text { Able to follow instructions }\end{array}$ \\
\hline Camping & $\begin{array}{l}\text { Avoiding any actions that can cause problems } \\
\text { Asking permission first before using the } \\
\text { belonging of others } \\
\text { Maintaining cleanliness and tidiness } \\
\text { Practicing completing homework }\end{array}$ \\
\hline $\begin{array}{l}\text { Group } \\
\text { discussion }\end{array}$ & $\begin{array}{l}\text { Using the right tone } \\
\text { Ignoring distractions } \\
\text { Listening to other people talking } \\
\text { Discipline to do the task }\end{array}$ \\
\hline
\end{tabular}

\subsubsection{Assertion}

Assertiveness is an interpersonal ability to communicate one's willingness, feeling, and thought to others while maintaining and respecting the rights and feelings of others. The activities that influence the 
formation of the indicators of the assertion aspect are summarized in the following Table 2.

Table 2. Activities and Indicators of Assertion Aspect Formed

\begin{tabular}{|l|l|}
\hline Activities & Indicators of Assertion Aspect Formed \\
\hline Presentation & $\begin{array}{l}\text { Able to start a conversation } \\
\text { Able to express feelings appropriately }\end{array}$ \\
\hline Market day & $\begin{array}{l}\text { Able to invite others to participate in an activity } \\
\text { Interacting with confidence }\end{array}$ \\
\hline Outing class & $\begin{array}{l}\text { Able to make friends easily } \\
\text { Willing to help } \\
\text { Asking for help when needed } \\
\text { Defending friends who are treated improperly } \\
\text { Participating in various activities }\end{array}$ \\
\hline Worksheet & $\begin{array}{l}\text { Giving and accepting compliments } \\
\text { Appreciating the work of others }\end{array}$ \\
\hline
\end{tabular}

\subsubsection{Responsibility}

Responsibility is human awareness of both intentional and unintentional behaviors or acts. Responsibility also means acting as an expression of awareness of the obligation. The activities that influence the formation of the indicators of the responsibility aspect are summarized in the following Table 3.

Table 3. Activities and Indicators of Responsibility Aspect Formed

\begin{tabular}{|l|l|}
\hline Activities & Indicators of Responsibility Aspect Formed \\
\hline Outing class & $\begin{array}{l}\text { Caring about other people } \\
\text { Responsibility to the environment }\end{array}$ \\
\hline $\begin{array}{l}\text { Routine worship } \\
\text { activities together }\end{array}$ & $\begin{array}{l}\text { Able to queue in an activity } \\
\text { Responsibility to God }\end{array}$ \\
\hline Backpacking & $\begin{array}{l}\text { Responsibility to oneself and his friends } \\
\text { Liked and accepted by others } \\
\text { Answering the other person well }\end{array}$ \\
\hline Worksheet & Reporting correctly and honestly \\
\hline
\end{tabular}

\subsubsection{Empathy}

Empathy is the ability to see situations from the perspective of others. This involves the point of view, emotions, and difficulties experienced by someone. Individuals who have empathy can put themselves in the shoes of others who have disasters and feel the sadness of others. The activities that influence the formation of the indicators of empathy are summarized in the following Table 4.

Table 4. Activities and Indicators of Empathy Aspect Formed

\begin{tabular}{|l|l|}
\hline Activities & Indicators of Empathy Aspect Formed \\
\hline $\begin{array}{l}\text { Social service } \\
\text { and social } \\
\text { projects }\end{array}$ & $\begin{array}{l}\text { Giving smile to others } \\
\text { Listening to the problems of others and thinking } \\
\text { of the ways to help } \\
\text { Defending others who have disasters or are } \\
\text { treated unfairly } \\
\text { Giving an example to others to do good } \\
\text { Able to discuss problems or opinions with } \\
\text { others well }\end{array}$ \\
\hline $\begin{array}{l}\text { No ranking } \\
\text { system }\end{array}$ & Respecting the achievements of others \\
\hline $\begin{array}{l}\text { Watching } \\
\text { videos } \\
\text { together }\end{array}$ & $\begin{array}{l}\text { Able to understand other people's feelings } \\
\text { Feeling sorry for others who have got } \\
\text { misfortunes }\end{array}$ \\
\hline
\end{tabular}

\subsubsection{Self-control}

Self-control is defined as the ability to arrange, guide, regulate, and direct the form of behavior that can lead to positive consequences. Self-control is one of the potentials that can be developed and used by individuals in their lives, including in dealing with conditions in the surrounding environment. The activities that influence the formation of the indicators of the self-control are summarized in the following Table 5.

Table 5. Activities and Indicators of Empathy Aspect Formed

\begin{tabular}{|c|c|}
\hline Activities & $\begin{array}{lrl}\text { Indicators of Self-Control } \\
\text { Aspect Formed }\end{array}$ \\
\hline Exemplary teacher attitude & $\begin{array}{l}\text { Able to control emotions } \\
\text { Responding to other people's } \\
\text { behavior appropriately }\end{array}$ \\
\hline Instilling harmony in school & $\begin{array}{l}\text { Willing to accept sanctions } \\
\text { from others } \\
\text { Accepting criticism without } \\
\text { anger } \\
\text { Not showing anger when } \\
\text { expressing disapproval } \\
\text { Refusing politely }\end{array}$ \\
\hline Counseling & $\begin{array}{l}\text { Able to ignore distractions } \\
\text { Avoiding any behavior that } \\
\text { can cause problems } \\
\text { Compromising with the } \\
\text { behavior/opinions of others }\end{array}$ \\
\hline $\begin{array}{l}\text { Applying 5S (Senyum [smile], } \\
\text { Salam [greet], Sapa [say hello], } \\
\text { Sopan [be polite], and Santun } \\
\text { [be respectful]) }\end{array}$ & Behaving well \\
\hline
\end{tabular}

\section{Discussion}

\subsection{Lesson Planning}

The lesson planning process at school is usually carried out by classroom teachers, but, in Bengawan Solo Nature School, it is carried out jointly by the teacher and students. The school takes a major theme in accordance with the national education curriculum that is developed according to the guidelines of the four pillars of curriculum in the nature school. The major theme will be broken down into several sub-themes by each teacher according to the student interests. The teacher together with the students selects learning materials according to the student interest and maps the learning materials into several themes to accommodate the desires and interests of the students in learning, so they will be more enthusiastic in learning [55]. Furthermore, the division of learning themes is to make students focus on learning something. If not, the focus of students in learning will be gone and unstructured. Through this theme, students will understand the sequence of the material to be taught later on [56][57].

The mapping of themes and used learning concepts is spider web type. Spider web is a thematic learning 
approach that combines multidiscipline or several subjects that are interrelated and bound together with one theme [54]. The development of this approach begins with determining a major theme, which is then developed into several sub-themes by showing the relationship between fields of study. After that, various learning activities are arranged that support the prepared themes [58][59]. Spider web can increase student motivation because theme selection is based on student interest [60]. Spider web allows the creation of meaningful learning where students can construct their own understanding directly and learning feels more fun because the students play an active role in every activity [58][61].

After making the concept map of the learning theme, the teacher prepares detailed plan for activities carried out for a week containing the implementation time, details of the subject matter, learning scenarios, and the learning media to be used. The teacher also tells the students about the equipment needed for a week to support learning. Learning is a complex and situational process so we cannot predict the difficulties that may arise. Through this well-prepared lesson planning, the teacher can easily predict the difficulties that will be faced, anticipate various problems that may arise, and prepare various anticipatory efforts on obstacles that may arise [62]-[64].

Closing is also done at the end of each lesson. Closing is a routine activity where the teacher reminds the students of what they must bring and prepare for the next learning. Closing is a form of the seriousness of the school in planning the learning carefully. In closing activities, students indirectly get support and attention from the teacher. According to [65][66] students who receive support and attention from their teacher will be more motivated to engage in teaching and learning activities than those who do not.

\subsection{Learning Implementation}

In implementing learning, Bengawan Solo Nature School always partners with parents to improve the achievements of their students. The teacher intensively contacts the parents to remind them of the preparation for learning in one week in detail activities. In the learning process, parents are highly involved in homework. They are very cooperative to help the students to complete their homework. Parents are involved in helping monitor the cognitive aspects and emotional development of the students. Furthermore, the teacher will coordinate, discuss, and cooperate with the parents of the students who have a few emotional problems. Sometimes, the teacher stays at the student's house to find out his behavior at home and the cause of the behavior. [67] believed that education at home and school must be in line. It means that parents and schools must keep pace with the times in educating the students now to prevent conflicts and confuse the students. The benefit of the involvement of parents in education is that the students can increase their attendance at school, behave, and act appropriately. Besides, parental involvement can be a source of enthusiasm for the students and improve their performance and personality [68][69]. Learning at Bengawan Solo Nature School applies the student-centered method, where students are involved in almost all aspects of learning while the teacher acts as a facilitator. The used learning models are also diverse in accordance with student development. The commonly applied learning model is a contextual learning model that links the material being studied with students' real-world situations. This contextual model encourages students to make connections between the knowledge they have and the application in their lives so that learning takes place naturally in the form of activities where the students work and experience, not the transfer of knowledge from the teacher to students [70]-[72].

In addition, the teacher also applies a problem-based learning model that is considered capable of improving students' problem-solving, critical- and creative-thinking skills. This is supported by the opinions of some experts stating that problem-based learning models can improve students' critical-thinking, social, and problem-solving skills in daily life [73][74]. Learning media varies according to the material to be taught. The commonly used learning media are interactive multimedia and real objects in the natural environment around the school. The use of learning media can clarify the presentation of messages or learning material in the verbalistic form and overcome the limited space, time, and senses [75][76]. Bengawan Solo Nature School uses learning resources in the form of natural environments because natural environments that are familiar for students can provide direct experience and create an innovative atmosphere while staying focused on the learning objectives. This is in line with the opinion of [77] stating that a school environment is a unit of space that influences the construction of student knowledge, the formation of attitudes, and the development of student potential.

There are also several activities that influence social skills. The activities and their relation to the social-skill aspects are described as follows.

\subsubsection{Activities for Cooperation Aspect}

The cooperation of the students can be seen in group discussion activities. Discussion activities are conducted almost every day in learning because the learning in this school is student-centered. During the discussion, the teacher only acts as a guide who will guide and direct the students to make wise decisions. In the discussion activities, we can see the students' ability to work together in dividing their roles according to their abilities. Every student gets the same opportunity in giving their opinions; if there are different opinions, they will not immediately judge them wrong. This is in line with the theory of [78], which states that discussion is a process of interaction involving several people to contribute their ideas, share 
information, solve problems, and train each other's communication skills to achieve goals. All these activities are important components of social skills.

In discussion activities, students are required to use the right tone in communicating with group members to avoid misinformation or misunderstanding [79]. In addition, through group discussions, students are required to be disciplined in doing joint tasks with the time limit given by the teacher. From the assignments and deadlines given by the teacher, the students fulfill the indicator of being able to manage time and conditions by ignoring distractions that can interfere with the work of group assignments [80].

Outbound activities can also improve the student cooperation aspect. In outbound activities, students are usually divided into groups of classes and gender. Through this division of groups, it is expected that students will have a high sense of cooperation. The distance in the exploration is quite far for students so that they have to stick together and understand each other among group members. The decision is on the group members, so good cooperation is needed to make the outbound activities successful. In the absence of interference from the facilitator, students will avoid actions that can cause problems in the group. In addition, preparing anything by themselves until they finally get accustomed to being independent can train the students to complete the homework. This outbound will teach the students how to better respect and preserve nature and everything well [81]-[83] because outbound is usually held in areas that blend with nature.

\subsubsection{Activities for Assertion Aspect}

The assertion aspect in the form of communicating with confidence is formed through a business curriculum activity called market day, which is held to help students interact with confidence. The process of buying and selling in the market day where a seller should offer his product teaches the students to be able to invite others to participate in buying and selling activities, for example, people passing by. The students practice how to start a communication with the buyer and involve the buyer in buying and selling activities. This is supported by [84]which states that social skills are behaviors, actions, and attitudes that are formed from routine training or habituation. [85] also stated that to improve social skills, it begins with providing a social environment that makes students inevitably have social interaction.

After the students complete their buying and selling activities, they will present the results, starting from the planning stage, collecting capital, to calculating profits in front of the class. Through presentation activities, the students are trained to be brave to speak in front of others. The presentation also teaches them how to start and close a conversation well, how to express opinions well without hurting others, and how to confidently express their ideas.
Through presentations, students are trained to get used to speaking and presenting in public, which can increase their confidence in socializing [86][87].

Furthermore, in outing class activities, the indicators of cooperation are being able to make friends easily, willing to help, asking for help when needed, and participating in various activities simultaneously. Outing class allows students to interact with outsiders; for example, when they learn how to harvest rice, they will meet farmers and establish relationships with them to obtain information related to group assignments. Students will also help each other in the group, and, indirectly, they divide the tasks so that they can do various activities at one time. Outing class allows the students to be actively involved in developing their potential, fosters their confidence in interacting, and builds their own knowledge by working instead of memorizing [88][89].

\subsubsection{Activities for Responsibility Aspect}

The responsibility aspect of the students can be seen in the activities of habituation of congregational prayers and backpacking. The habituation of congregational prayers is a routine activity held by Bengawan Solo Nature School, including the Duha congregational prayer, Friday congregational prayer, and reading Quran together. The students are aware of their responsibilities to God by performing worship without coercion. The habit of congregational prayers is a way to provide a positive environment to change the students to be more religious people who have good morals [90]. When the students prepare for congregational prayers, they must queue for the ablution, alternately pray with other classes, and queue up when leaving the mosque. Thus, the indicator of queuing up in an activity which is an aspect of responsibility is evident in this congregational prayer activity. Queuing is a form of responsibility to others because it means that the students can obey their obligations to respect the rights of others with discipline [91].

Furthermore, in backpacking activities, the students are faced with situations that make them think about survival with their group friends independently. The teacher only acts as a supervisor. The students do all the preparations such as food supplies, identify the travel routes, and find the lodging by themselves. The teacher actually has asked permission from the surrounding community so that students can stay at one of the residents' houses. However, the students are asked to ask permission independently so that the indicator of responsibility in the form of being able to be liked and accepted by others, and the indicator of responding to others well can grow. Being aware of the duties and obligations of each is an attitude of student responsibility [92]. In this backpacking activity, the students also inevitably have to take care of themselves so as not to inconvenience their group friends, share food supplies, and look after each other to smooth their journey to the destination. This trains the responsibility to 
themselves and their friends. Backpacking activities are also usually held in the natural environment so students can learn how to care for their natural environment [93]-[95].

\subsubsection{Activities for Empathy Aspect}

Student empathy can be improved through social service activities, social projects, and the routine of watching videos together. The social activities that are held routinely are varied; some are held by classes; some are held by parents or schools. This social service usually leads to a certain phenomenon, such as natural disasters. The forms of social service that are usually held are, such as, the distribution of staple food and fundraising. In contrast to social services, social projects are held for school members or the community around the school. The social projects are usually intended for those in need. For example, the fifth-grade students will design a social project with the teacher to help their friends in need, which is then submitted to the school and parents. The habituation of social service and social projects is an example of doing good deeds by the students to the community. The social service conducted by the students is a form of love, mutual help, and empathy for those in need [96][97].

Furthermore, the routine of watching videos together is the activity where students are invited by the teacher to watch videos that inspire empathy such as the video of the victims of natural disasters, victims of the conflict between countries, hunger phenomena, victims of disease outbreaks, etc. Many students appear to be very empathetic with these victims until they shed tears and become grateful for their condition, which is better than the victims in the video. This shows that the activity of watching a video together can improve the indicators of empathy in the form of being able to understand the feelings of others and feeling sorry for others who have misfortune or disasters. Empathy is a basic social skill from the character of heroism that must be instilled early on because empathy is the foundation of the behaviors of sharing, helping one another, and getting rid of students' selfishness [98][99].

\subsubsection{Activities for Self-control Aspect}

The aspect of student self-control is seen in the behavior of students at school both in the learning process and outside of learning. Bengawan Solo Nature School implements harmony in the classroom. The teacher instills harmony through examples, meaning that the teacher exemplifies harmonious life behavior so that the students can apply it by imitating the teacher's example. The internalization of harmony in the school has been a habit for years and passed down to the teachers and students. Before starting the new academic year, the first-time students meet with the teacher; they will discuss the consequences that the students must take if they cannot maintain peace and harmony with their friends. Living in harmony is a form of interaction of individuals who have social skills because living in harmony means an attitude of maintaining good relations with others, not creating problems, and living by always helping each other [30],[31],[39].

The students from higher classes can control themselves better than lower-class students because they have not been able to distinguish right from wrong. Then, the teacher always emphasizes that higher class students are the role models for their juniors so that they can control themselves to do bad things. However, there may be some students who have problems with self-control. Therefore, the school holds routine counseling activities for some problematic students. The purpose of this counseling is to improve indicators of self-control, such as being able to ignore distractions, avoid behaviors that can cause problems, and accept or compromise with other people's opinions. This is in line with the opinion of [96] stating that counseling can help students project their emotions and find solutions to the problems they experience. Appropriate counseling can effectively help students in overcoming conflicts experienced and change them into individuals who are more accepted in their environment [100][101].

\subsection{Learning Evaluation}

The learning at Bengawan Solo Nature School is evaluated using test and non-test techniques. The commonly used test instruments are open-ended and oral tests because open-ended tests are considered effective for evaluating and measuring the depth and mastery of students in understanding the material taught [102]. Then, the teachers routinely use non-test learning evaluation instruments such as questionnaires, worksheets, interviews, project presentations, and the students' works and portfolios. The questionnaire is used to determine the level of student motivation, types of learning styles, students' initial abilities, and other variables that influence the course of the study. The teacher chooses the questionnaire because it can collect more information and data, and the respondents can answer freely without being studied and assessed [103]. The portfolio is a collection of the results of tasks/tests or the work of the students associated with predetermined standards or criteria. Portfolios allow teachers to access students' abilities to create, write, produce various types of academic assignments, assess their skills, intervene in the process, and identify student weaknesses that need to be improved [104]. Then, worksheets containing reports on student activities from the preparation to the follow-up activities and presentations in front of the class are considered effective in developing students' critical and creative thinking [105].

At the end of the semester, parents get two types of final reports, namely the final report according to the format of the Department of Education and Culture and 
the final report typical of Bengawan Solo Nature School. The final report from the Department of Education and Culture contains the figures while the school's final report informs the achievement of four pillars of curriculum that are applied comprehensively. This is in line with the opinions of some experts stating that evaluation of learning outcomes is well implemented if it is carried out unanimously and comprehensively [106]-[108]. The evaluation of learning outcomes must include various aspects that can describe the development or change in the attitudes, knowledge, and skills of the students [109].

\section{Conclusions}

Based on the results and the discussion above, it can be concluded that in developing social skills, teachers should carry out lesson planning sell; students must be involved in choosing learning materials according to their interests; the teacher must also have broad insights to develop learning materials that raise the themes of social environment; there should be clear guidelines in the form of a national education curriculum and four pillars of curriculum that are applied at Bengawan Solo Nature School. In implementing social-skill learning, there are several aspects to be considered, such as the involvement of parents in educating the students, diverse methods, models, media, and the sources of student learning, as well as diverse activities that influence social skills. The diverse activities include outbound, market day, backpacking, social service, social projects, and counseling. Developing social skills requires evaluation of learning using various assessment instruments with a high level of effectiveness and various methods of evaluation. Then, the reporting of student learning outcomes should include not only cognitive aspects but also affective and skill aspects comprehensively.

\section{Acknowledgments}

The researcher would like to thank Sebelas Maret University for giving the 2019 Doctoral Scholarship and Research Dissertation Research Grant.

\section{REFERENCES}

[1] A. Jaedun, L. Hariyanto, E. R. Nuryadin. An Evaluation of The Implementation of Curriculum 2013 at The Building Construction Department of Vocational High Schools in Yogyakarta, Journal of Education, Vol. 7, No. 1, 2014.

[2] UNESCO. Education for All, 2000-2015: Achievements and Challenges, Global Monitoring Report, UNESCO Publication, Paris, 2013.

[3] M. Bialik, C. Fadel, B. Triling, P. Nilsson. Skills for the $21^{\text {st }}$
Century: What Should Students Learn? Center for Curriculum Redesign, Boston, 2015.

[4] D. Cretu. Fostering $21^{\text {st }}$ Century Skills for Future Teachers, Conference: Edu World 7th International Conference, 672-681, 2017.

[5] L. A. Witt, G. R. Ferris. Social Skills as Moderator of the Conscientiousness - Performance Relationship: Convergent Results Across Four Studies, Journal of Applied Psychology, Vol. 88, No. 1, 809-821, 2003.

[6] N. Cimen, S. Kocyigit. A Study on the Achievement Level of Social Skills Objectives and Outcomes in the Preschool Curriculum for Six Years Old, Procedia Social and Behavioral Sciences, Vol. 2, 5612-5618, 2010.

[7] W. L. Stone, L. Ruble, E. Coonrod, S. Hepburn, M. Pennington. TRIAD Social Skills Assessment Manual, Treatment and Research Institute for Autism Spectrum Disorders, Nashville, 2002.

[8] C. R. Cook., F. M. Gresham, L. Kern. Social Skills Training for Secondary Students with Emotional and/or Behavioral Disorders: A Review and Analysis of the Meta-Analytic Literature, Journal of Emotional and Behavioral Disorders, Vol. 16, 131-144, 2008.

[9] M. Jureviciene, I. Kaffemaniene, J. Ruskus. Concept and Structural Components of Social Skills, Socialiniai Mokslai, Vol. 3, No. 86, 42-52, 2012.

[10] M. Welsh, R. D. Park, K. Widaman, R. O'Neil. Linkages Between Children's Social and Academic Competence: A Longitudinal Analysis, Journal of School Psychology, Vol. 39, 463-481, 2001.

[11] A. Widjaja, E. J. Saragih. Analysis on the Effect of Hard Skills, Intrapersonal and Interpersonal Skills towards the Performance of Nurses (A Case Study on the Alumni of Husada Hospital Academy, Jakarta, Indonesia), Journal of Research in Business and Management, Vol. 6, No. 5, 31-38, 2018.

[12] M. P. H. Angeles. Teaching Efficacy, Interpersonal, Intrapersonal Skills and Teaching Performance in the Tertiary School, International Peer Reviewed Journal, Vol. 2, 17-25, 2012.

[13] J. O. Adeoti, I. L. Adedoyin. The Impact of Interpersonal Factors on Quality Health Delivery in Kwara State Government Hospitals, African Journal of Social Sciences, Vol. 2, No. 2, 34-40, 2012.

[14] C. Canney, A. Byrne. Evaluating Circle Time as A Support to Social Skills Development - Reflections on a Journey in School-Based Research, British Journal of Special Education, Vol. 33, No. 1, 19-24, 2006.

[15] R. A. Fabes, C. L. Martin, L. D. Hanish. Children's Behaviors and Interactions with Peers. In K. H. Rubin, W. M. Bukowski, \& B. P. Laursen (Eds.), Social, Emotional, and Personality Development in Context. Handbook of Peer Interactions, Relationships, And Groups. Guilford Press, New York, 2009.

[16] K. H. Rubin, W. M. Bukowski, J. G. Parker. Peer Interactions, Relationships, and Groups. In N. Eisenberg (Ed.), Handbook of Child Psychology $\left(6^{\text {th }}\right.$ ed.). John Wiley \& Sons, New Jersey, 2006. 
[17] J. Zins, R. Weissbert, M. Wang, H. Walberg, H. Building Academic Success on Social and Emotional Learning: What does the Research Say? Teachers College Press, New York, 2004 .

[18] A. Bellack, K. Mueser, S. Gingerich, J. Agresta. Social Skills Training for Schizophrenia: A Step-by-Step Guide, The Guilford Press, New York, 2004.

[19] S. H. Spence. Social skills training with children and young people: Theory, evidence and practice, Child and Adolescent Mental Health, Vol. 8, No. 2, 84-96, 2003.

[20] F. M. Gresham, S. N. Elliott. Social skills improvement system rating scales, Pearson, Minneapolis, 2008.

[21] Y. J. Sung. The Effect of Social Skills on Academic Achievement of Linguistically Diverse Elementary Students: Concurrent and Longitudinal Analysis, Faculty of the Virginia Polytechnic Institute and State University, Virginia, 2009.

[22] E. Gurbuz, B. Kiran. Research of Social Skills of Children who Attend to Kindergarten According to the Attitudes of Their Mothers, Journal of Education and Training Studies, Vol. 6, No. 3, 2018.

[23] J. Boyd, W. S. Barnett, E. Bodrova, D. J. Leong, D. Gomby. Promoting Children's Social and Emotional Development Through Preschool Education, National Institute for Early Education Research, Canada, 2005.

[24] J. Brodeski, M. Hembrough. Improving Social Skills in Young Children, Saint Xavier University Chicago, Illinois, 2007.

[25] H. Ikesako, K. Miyamoto. Fostering Social and Emotional Skills Through Families, Schools and Communities: Summary of International Evidence and Implication for Japan's Educational Practices and Research, OECD Education Working Papers No. 121, OECD Publishing, Paris, 2015.

[26] N. J. Patrick. Social Skills for Teenagers and Adults with Sperger Syndrome, Jessica Kingsley Publisher, London, 2008.

[27] M. Beheshtifar, T. Norozy. Social Skills: A Factor to Employees' Success, International Journal of Academic Research in Business and Social Sciences, Vol. 3, No. 3, 74-79, 2013

[28] T. Okumura, E. Usui. Do Parents' Social Skills Influence Their Children's' Sociability? IZA Discussion Paper, No. 5324, 89-97, 2010.

[29] L. Borghans, B. Weel, B. A. Weinberg. People Skills and the Labor-Market Outcomes of Underrepresented Groups, CPB Discussion Paper, Illinois, 2006.

[30] K. M. Kilic, F. A. G. Aytar. The Effect of Social Skills in Early Childhood, the Relationship between Social Skills and Temperament, Education and Science, Vol. 42, No. 191, 185-204, 2017.

[31] O. Gokel, G. Dagli. Effect of Social Skill Training Program on Social Skills of Young People, EURASIA Journal of Mathematics, Science and Technology Education, Vol. 13, No. 11, 7365-7373, 2017.

[32] Y. Takahashi, K. Okada, T. Hoshino, T. Anme.
Developmental Trajectories of Social Skills during Early Childhood and Link to Parenting Practices in a Japanese Sample, PLOS ONE, Vol. 10, No. 8, 1-14, 2015.

[33] C. W. Stratton, M. J. Reid. Strengthening Social and Emotional Competence in Young Children-The Foundation for Early School Readiness and Success, Infants and Young Children, Vol. 17, No. 2, 96-113, 2004.

[34] C. Awbrey, A. Longo, A. Lynd, C. Payne. Increasing Social Skills of Elementary School Students through the Use of Literature and Role Playing, Saint Xavier University \& Pearson Achievement Solutions, Chicago, 2008.

[35] E. G. Karakaya, M. Tufan. Social Skills, Problem Behaviors and Classroom Management in Inclusive Preschool Settings, Journal of Education and Training Studies, Vol. 6, No. 5, 123-134, 2018.

[36] C. Campbell, D. J. Hansen, D. W. Nangle. Social Skills and Psychological Adjustment, Springer, New York, 2010.

[37] P. Loukatari, O. Matsouka, K. Papadimitriou, S. Nani, V. Grammatikopoulos. The Effect of a Structured Playfulness Program on Social Skills in Kindergarten Children, International Journal of Instruction, Vol. 12, No. 3, 237-252, 2019.

[38] A. M. Crawford, K. Manassis. Anxiety, Social Skills, Friendship Quality, and Peer Victimization: An Integrated Model, Journal of Anxiety Disorders, Vol. 25, No. 7, 924-931, 2011.

[39] M. M. McClelland, F. J. Morrison, L. H. Deborah L. H. Children at risk for early academic problems: the role of learning-related social skills, Early Childhood Research Quarterly, Vol. 15, No. 3, 307-329, 2000.

[40] A. D. S. Goncalves, V. L. D. Araujo, S. Pereira, I. X. Moreira. Utilizing Audiovisual Media and Learning Motivation on Student Achievement of Social Department Grade VIII Student Fatumeta, Dili, International Research-Based Education Journal, Vol. 1, No. 1, 1-10, 2017.

[41] E. Ratnaningsih. Evaluating a Classroom Process, METATHESIS, Vol. 1, No. 1, 92-103, 2017.

[42] M. Sadik. Educational Planning: Approaches, Trends, and Learnings A Case Study of the Kurdistan Region of Iraq (KRI), SSRG International Journal of Economics Management Studies, Vol. 5, No. 6, 1-9, 2018.

[43] I. Gunawan. Indonesian Curriculum 2013: Instructional Management, Obstacles Faced by Teachers in Implementation and the Way Forward, $3^{\text {rd }}$ International Conference on Education and Training, Atlantis Press, Vol. 128, 56-63, 2017.

[44] B. Johns, E. P. Crowley, E. Guetzloe. The Central Role of Teaching Social Skills, Focus on Exceptional Children, Vol. 37, No. 8, 1-8, 2005.

[45] N. Salamuddin, M. T. Harun. Facilitating the Process of Learning Social Skills through Humanistic Physical Education, Procedia Social and Behavioral Sciences, Vol. 9, 223-227, 2010.

[46] F. Ioannis, N. S. Maria. Development and Growing of Social Skills in Teaching Procedure: Teaching Actions and Suggestions, Journal of Education and Human Development, 
Vol. 6, No. 1, 120-128, 2017.

[47] L. O'Brien. Learning Outdoors: The Forest School Approach, Education 3-13, Vol. 37, No. 1, 45-60, 2009.

[48] F. Harris. Outdoor Learning Spaces: The Case of Forest School, Area, Vol. 6, No. 30, 1-9, 2017.

[49] S. P. Daniati, S. Subiyantoro, S. S. Fadhilah. Natural School Culture as a Free And Fun Alternative Education in Building the Students' Character, Elementary Education Online, Vol. 18, No. 1, 331-342, 2019.

[50] Suhendi, S. Murdiani. Belajar Bersama Alam, SoU Publisher, Bogor, 2012.

[51] A. Crescentini, G. Mainardi. Qualitative Research Articles: Guidelines, Suggestions and Needs, Journal of Workplace Learning, Vol. 21, No. 5, 431-439, 2009.

[52] J. W. Creswell, C. N. Poth. Qualitative Inquiry and Research Design. Choosing Among Five Approaches (4th Edition ed.), SAGE Publishing, California, 2018.

[53] M. D. C. Tongco. Purposive Sampling as a Tool for Informant Selection, Ethnobotany Research \& Applications, Vol. 5, 147-158, 2007.

[54] M. B. Miles, A. M. Huberman. Qualitative Data Analysis: An Expanded Sourcebook, SAGE Publications, California, 1994.

[55] A. Paolini. Enhancing Teaching Effectiveness and Student Learning Outcomes the Journal of Effective Teaching, Vol. 15, No. 1, 20-33, 2015.

[56] N. Ain. Holistic Thematic Learning in the Elementary School: Is it Thematic and Holistic? Atlantis Press: Advances in Social Science, Education and Humanities Research, Vol. 158, 919-928, 2017.

[57] Chumdari, S. Anitah, Budiyono, N. Suryani. Implementation of Thematic Instructional Model in Elementary School, International Journal of Education Research Review, Vol. 3, No. 4, 23-31, 2018

[58] S. B. Khoza. Using Curricular Spider Web to Explore a Research Facilitator's and Students' Experiences, South African Journal of Higher Education, Vol. 29, No. 2, 122-143, 2015.

[59] J. V. D. Akker. Building Bridges: How Research may Improve Curriculum Policies and Classroom Practices, Beyond Lisbon 2010: Perspectives from research and development for educational policy in Europe. Sint-Katelijne-Waver, Belgium, 2010.

[60] T. Plomp \& N. Nieveen. An Introduction to Educational Design Research, Netherlands Institute for Curriculum Development, Netherlands, 2007.

[61] A. V. D. Laan, J. Bron. The Spider Web: Framework for Assessing Student Participation, Netherlands Institute for Curriculum Development, Netherlands, 2018.

[62] M. Priestley, G. Biesta. Reinventing the Curriculum: New trends in curriculum policy and practice, Bloomsbury Academic, London, 2013.

[63] T. Fujii. Designing and Adapting Tasks in Lesson Planning: A Critical Process of Lesson Study, The International Journal of Mathematics Education, Vol. 48, No. 4, 1-13,
2016.

[64] V. Cicek, H. Tok. Effective Use of Lesson Plans to Enhance Education in U.S. and Turkish Kindergarten through 12th Grade Public School System: A Comparative Study, International Journal of Teaching and Education, Vol. 2, No. 2, 10-20, 2014.

[65] J. Dorovolomo, H. P. Phan, J. Maebuta. Quality Lesson Planning and Quality Delivery: Do They Relate? International Journal of Learning, Vol. 17, No. 3, 447-456, 2010.

[66] S. Jarvela. Social and Emotional Aspect of Learning, Springer, UK, 2011.

[67] F. Koca. Motivation to Learn and Teacher-Student Relationship. Journal of International Education and Leadership, Vol. 6, No. 2, 1-20, 2016.

[68] C. Deforges, A. Abouchaar. The Impact of Parental Involvement, Parental Support and Family Education on Pupil Achievement and Adjustment: A Literature Review, Research Report of Queen's Printer, Bureau, 2003.

[69] J. Hughes, O. Kwok. Influence of Student-Teacher and Parent-Teacher Relationships on Lower Achieving Readers' Engagement and Achievement in the Primary Grades, Journal Educational Psychology, Vol. 99, No. 1, 39-51, 2007.

[70] L. Emerson, J. Fear, S. Fox, E. Sanders. Parental Engagement in Learning and Schooling: Lesson from Research, Family-School \& Community Partnership Bureau, Canberra, 2012.

[71] A. Newchurch. The Impact of Parental Involvement on Student Success: School and Family Partnership from The Perspective of Parents and Teachers, Kennesaw State University, Kennesaw, 2017.

[72] J. Johnny. Contextual Learning: A Model for Learning \& Instruction in Math, Institut Pendidikan Guru Kampus Temenggong Ibrahim, Malaysia, 2008.

[73] A. Nawas. Contextual Teaching and Learning (CTL) Approach through REACT Strategies on Improving the Students' Critical Thinking in Writing, International Journal of Applied Management Science, Vol. 4, No. 7, 46-49, 2018

[74] C. H. Silver. Problem-Based Learning: What and How Do Students Learn? Educational Psychology Review, Vol. 16, No. 3, 235-266, 2004.

[75] A. S. Argaw, B. B. Haile, B. T. Ayale, S. G. Kuma. The Effect of Problem-Based Learning (PBL) Instruction on Students' Motivation and Problem Solving Skills of Physics, EURASIA Journal of Mathematics Science and Technology Education, Vol. 13, No. 3, 857-871, 2017.

[76] M. J. Eady, L. Lockyer. Tools for Learning: Technology and Teaching Strategies, Learning to Teach in the Primary School, Cambridge University Press, Cambridge, 2013.

[77] Ahamad, A. Sakat, M. Zaid, M. Z. M. Zin. Educational Technology Media Method in Teaching and Learning Progress, American Journal of Applied Sciences, Vol. 9, No. 6, 874-878, 2012

[78] S. Alimah, H. Susilo, M. Amin. Natural Environment Exploration Approach: The Case Study in Department of 
Biology, Universitas Negeri Semarang, International Journal of Environmental \& Science Education, Vol. 11, No. 12, 5710-5717, 2016.

[79] R. E. Corden. Group Discussion and the Importance of a Shared Perspective: Learning from Collaborative Research, Qualitative Research, Vol. 1, No. 3, 347-367, 2001.

[80] L. D. Jager, R. Evans. Misunderstanding During Instructional Communication as Related to Oral Proficiency, Southern African Linguistics and Applied Language Studies, Vol. 31, No. 1, 2013.

[81] R. Meleady, T. Hopthrow, R. J. Crisp. The Group Discussion Effect, Personality and Social Psychology Review, Vol. 17, No. 1, 1-50, 2012.

[82] T. J. Dickson, T. Gray, K. Mann. Australian Outdoor Adventure Activity Benefits Catalogue, University of Canberra, Australia, 2008

[83] A. L Carruthers. Emotional and Social Developmental Benefits of Summer Camp for Children: Examining the Relationship between Capital and Emotional Intelligence, University of Waterloo, Canada, 2013.

[84] G. Yildirim, G. O. Akamca. The Effect of outdoor learning activities on the development of preschool children, South African Journal of Education, Vol. 37, No. 2, 1-10, 2017.

[85] M. Klarin. Social Interaction among Children in Play Activities, University of Zadar, Croatia, 2015.

[86] T. Lawhon, D. C. Lawhon. Promoting Social Skills in Young Children, Early Childhood Education Journal, Vol. 28, 105-110, 2000.

[87] Nadiah, Arina, Ikhrom. The Students' Self Confidence in Public Speaking, Elite Journal: Journal of English Linguistics, Literature, and Education, Vol. 1, No 1, 1-11, 2019.

[88] L. S. Christie, Listyani. Teachers' Strategies to Improve Students' Self-Confidence in Speaking, Register Journal, Vol. 11, No. 2, 121-148, 2018.

[89] M. Behrendt, T Franklin. A Review of Research on School Field Trips and Their Value in Education, International Journal of Environmental \& Science Education, Vol. 9, 235-245, 2014.

[90] A. Darma, L. S. Agung, H. Joebagio. Application of Multicultural Outing Class Method in Man 2 Model Medan, International Journal of Multicultural and Multireligious Understanding, Vol. 5, No. 4, 288-297, 288-297, 2018.

[91] S. Schwebel. Spirituality and Wellbeing: Primary Teacher and School Counsellor Perspectives, Journal of Student Engagement: Education Matters, Vol. 7, No. 1, 2-27, 2017.

[92] P. Nieman, Calgary, Alberta, S. Shea. Effective Discipline for Children, Pediatrics Child Health, Vol. 9, No. 1, 37-41, 2004.

[93] A. S. Rahi. Information Attitude, Responsibility and Behavior of Prospective Teachers Towards Environment Education, International Journal of Informative \& Futuristic Research, Vol. 3, No. 2, 591-601, 2015.

[94] M. J. Stone, J. F. Petrick. The Educational Benefits of Travel
Experiences: A Literature Review, Journal of Travel Research, Vol. 56, No. 6, 721-744, 2013.

[95] C. Noy. Backpacker. In book: Encyclopedia of Tourism, Springer International Publishing, United States of America, 2015.

[96] K. Morris, W. Mason, P. W. B. Bywaters, B. Featherstone. Social Work, Poverty and Child Welfare Interventions, Child \& Family Social Work, Vol. 23, No. 1, 1-9, 2018.

[97] A. Body, E. Lau, J. Josephidou. Our Charitable Children Engaging Children in Charities and Charitable Giving, Canterbury Christ Church University, United Kingdom, 2019.

[98] K. A. S. Reichi. Promoting Empathy in School-Aged Children: Current Approaches and Implications for Practice, In book: School rampage shootings and other youth disturbances: Early preventive interventions, Edition: 1st edition, Routledge, New York, 2011.

[99] N. M. McDonald, D. S. Messinger. The Development of Empathy: How, When, and Why, University of Miami, US, 2011.

[100] E. E. Nkechi, E. E. Ewomaoghene, N. Egenti. The Role of Guidance and Counselling in Effective Teaching and Learning in Schools, International Journal of Multidisciplinary Studies, Vol. 1, No. 2, 36-48, 2016.

[101]F. Y. Sahin. The Evaluation of Counseling and Guidance Services Based on Teacher Views and Their Prediction Based on Some Variables, International Journal of Instruction, Vol. 2, No. 1, 59-76, 2009.

[102] H. C. Sari, O. Cengiz. The Use of Open Ended versus Closed Ended Questions in Turkish Classrooms, Open Journal of Modern Linguistics, Vol. 6, No. 2, 60-70, 2016.

[103] A. R. Artino, J. Larochelle, K. J. Dezee, H. Gehibach. Developing Questionnaire for Educational Research: AMEE Guide No. 87, Medical Teacher, Vol. 36, No. 6, 463-474, 2014.

[104] S. Odabasi. The Effect of Portfolios on Students' Learning: Student Teachers' Views, European Journal of Teacher Education, Vol. 34, No. 2, 161-176, 2011.

[105] S. Kurniawan, S. Suparman. Design of Student Worksheet Development Based on the Jigsaw Cooperative Learning Model, International Summit on Science Technology and Humanity, Indonesia, 2018.

[106] A. A. Aziz, K. M. Yusof, J. M. Yatim. Evaluation on the Effectiveness of Learning Outcomes from Students' Perspectives, Procedia - Social and Behavioral Sciences, Vol. 56, 22-30, 2012.

[107] L. Ramona, C. N. Bran. The Assessment of Learning Outcomes, Procedia - Social and Behavioral Sciences, Vol. 163, 125-131, 2014.

[108] G. Gallavara, E. Hreinsson, M. Kajaste, E. Lindesjöö, C. Sølvhjelm, A. K. Sørskår, M. Sedigh Zadeh. Learning outcomes: Common framework - different approaches to evaluation learning outcomes in the Nordic countries, Joint Nordic project 2007-2008, Nordic Quality Assurance Network for Higher Education, Finland, 2008. 
[109] S. Encheva S. Evaluation of Learning Outcomes. In: Luo X., Spaniol M., Wang L., Li Q., Nejdl W., Zhang W. (eds) Advances in Web-Based Learning - ICWL 2010, Lecture
Notes in Computer Science, Vol 6483. Springer, Berlin, 2010. 